\title{
Spatial Aspects of Urban Planning: A Case Study for Saint-Petersburg Agglomeration
}

\author{
Vitaly Garmanov ${ }^{1, *}$, Vladimir Bogdanov ${ }^{2}$, Vladimir Badenko ${ }^{2}$ and Vladimir Zaikin ${ }^{3}$ \\ ${ }^{1}$ St.Petersburg State Agrarian University, Russia \\ ${ }^{2}$ St. Petersburg State University, Universitetskaya nab., 7-9, St. Petersburg, 199034, Russia \\ ${ }^{3}$ Saint Petersburg State University of Architecture and Civil Engineering, Vtoraya Krasnoarmeiskaya \\ str. 4. St. Petersburg, 190005, Russia
}

\begin{abstract}
The spatial structure of the St. Petersburg metropolitan area and the system development of the territory based on the Master Urban Development Plan of St. Petersburg was analyzed. Perspective territories for housing, located in the north-west and south of the city were examined. The structure of housing development in the first agglomeration zone was described. Alluvial territories in the Gulf of Finland near the city for housing development was analyzed.
\end{abstract}

\section{Introduction}

Spatial aspects of urban planning was a much-debated subject in the most recent years especially in developing countries [1-3]. Appropriate problems includes the following issues: ecological, waste treatment, sustainable energy supply, land use planning, disaster management etc. [4-10]. Every municipalities in Russia and other countries is now moving forward in implementing sustainable urban development due to rapid urbanisation with increased population and rapid economic growth [11-16]. It should be noted, that during urban planning process experts use many approaches, including GIS-technologies, modelling, social and other kind of experiments, etc. [17-23]. Many studies considered the affection of the changes to the post-industrial urban planning framework on the existing mass-housing and industrial territories, which are under renovation and transformation nowadays [24-28]. Urban regeneration using new methodological base and the transformation in urban land-use planning system was also under considerable discussion [29]. In addition, many partial questions such as modelling of soil hydrological regimes and of ecological problems have been discussed [30,31].

In this paper the spatial structure of the St. Petersburg metropolitan area and the system development of the territory based on the Master Plan of St. Petersburg was analyzed. Perspective territories for housing, located in the north-west and south of the city were examined. The structure of housing development in the first agglomeration zone was described. Alluvial territories in the Gulf of Finland near the city for housing development was analysed.

\footnotetext{
* Corresponding author: coolhabit@yandex.ru
} 


\section{Materials and methods}

The St. Petersburg agglomeration is determined by the 1.5-hour drive for the habitants of the city. It covers an area within a radius of $60-70 \mathrm{~km}$ from the center of St. Petersburg. The St. Petersburg agglomeration could be divided into the following zones, see Fig.1:

1. The core of the metropolis (Roman numeral I on the Fig.1).

2. The first zone of the small towns around St. Petersburg (settlements-satellites).

3. The second zone of settlements-satellites (Roman numeral III on the Fig.1).

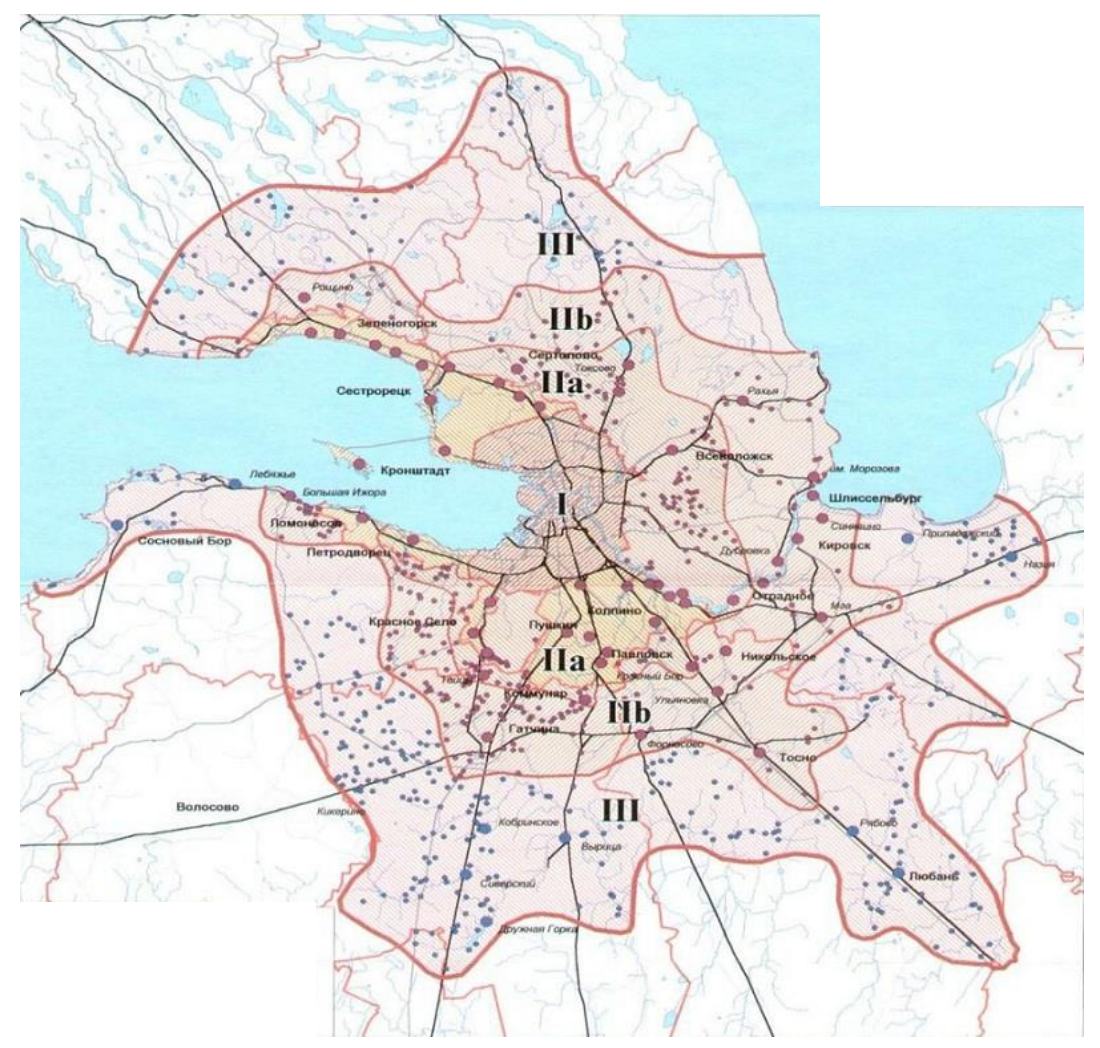

Fig. 1. The structure of the St. Petersburg metropolitan area with zones, numbered by Roman numerals.

The core of the megapolis includes the territory of St. Petersburg with high-density of population and almost continuous residential buildings. Approximate core area is 550 square kilometers. The megapolis population was about 4.3 million and the average population density was about 7818 people $/ \mathrm{km}^{2}$ in 2010 . The core of the agglomeration is practically a continuous territory of residential and office buildings. The land use in this area belongs to the category of settlement lands. The migration of industrial enterprises outside the core could be observed. However, the rate of this process is very low, despite the fact that appropriate program is the part of Master Urban Development Plan (MUDP) of St. Petersburg $[32,33]$.

The MUDP of St. Petersburg until 2015 is aimed on the $40 \%$ increase in the volume of housing stock (from 93 to $130 \mathrm{mln} \mathrm{m} 2$ ), because of the expected population growth and the increased levels of housing provision. The territories of the multi-family housing is expected to increase area from 16 thousand ha to 20-25 thousand ha, and of the one-family 
(individual) housing from 10 thousand ha to 13-15 thousand ha until 2016. The MUDP implies the increase of the housing volumes, taking into account the average housing provision of the resident population about 27 square meters of the total flat area per person.

Since the core agglomeration has a continuous built-up area, the main housing development is conducted mainly in the zone IIa as shown in Fig.1 (territory of settlements in the North-West and South). The largest territories for the most promising housing development are the area around Lahti spill and South-West (Strelna) and South Obuhovo (South Kupcino), Kudrovo (on the right bank of the Neva), Rych'i, New Devyatkino, North Valley [34].

Construction of apartment complexes, townhouses and cottages has already begun on these territories. Such housing has sufficiently high demand. The average price per square meter of living space in this area is smaller than on the territory of the agglomeration core (zone I in Fig.1). The housing market on the territory is basically represented by the objects of individual housing (mainly in the form of cottage settlements). One of the processes in the first zone of settlements is a process of suburbanization. This is why more and more residents of St. Petersburg tend to live in the suburbs. However, it should be noted that this process is often a «false suburbanization» because people buy cottages in the city suburbs, but reserve the apartment in the city.

The second zone of agglomeration (zone III in Fig.1) is less susceptible for changes in the structure of the city's land fund. The migration of industrial enterprises into this zone could be difficult due to the remoteness of the area from the city. The same reason is the limiting factor for the mass housing development there. The cottage settlements and other objects of individual housing appeared on the territory of the second zone. However, the total number of such housing is much smaller than the territory of the first zone of land use [28].

The authors considered the usage of the alluvial land areas in the Gulf of Finland as the one of the most important way to solve the problem of free space for housing development, due to the lack of the available space for housing development in the city. The creation of artificial lands on the water area of the Gulf of Finland is not the novel process for St. Petersburg. This kind of activities are historical. This is why such projects could have a greater chance of success. In this case, the new land resources could be generated and they would be located in close proximity to the developed areas of the city and prestigious suburbs areas.

A distinctive feature of the alluvial territories is the lack of restrictions on the creation of new engineering facilities and transport infrastructure, and the possibility of housing development with the high level of comfort. Integrated development of alluvial territories today is about $40 \%$ of all development projects, which are being implemented in the city. These kind of projects are gradually becoming a priority for city's territory growth.

The approximate area of the alluvial territories in the existing and planned projects were $11,000 \mathrm{~km}$ at the beginning of 2014 . This area is about $0.7 \%$ of the total area of St. Petersburg [11].

There are three large project for the construction of housing on the alluvial territories ("New Beach", "Marine Facade" Baltic Pearl") currently in St. Petersburg.

The land cost for the alluvial territories is equal to 1,500 rubles per square meter and above. The land cost in the Leningrad region and in St.Petersburg suburbs is about $600-800$ rubles per square meter. However, these territories are not desirable for the middle class population, because they do not have good facilities infrastructure and good transport accessibility [33]. 


\section{Results and discussions}

The development of St.Petersburg urban agglomeration has an affection on the changes in the structure of the land fund and land use. The most dynamic changes will take place in the first zone (IIa and IIb zones in Fig.1). For this reason, it is appropriate to consider the territory of the first zone of settlements-satellite of the St. Petersburg metropolitan area as the most susceptible for changes under the influence of agglomeration processes.

The question of different land categories transfer to the other categories rises with the expansion of the urban area with new construction. The primary issue is how the agricultural land could be transferred to the category of land settlements. Basically, this process occurs in the Leningrad region. The local authority of the Leningrad region enacted the law «On the transfer of land or land parcels from one category to another in the Leningrad region» (June 22, 2005 N 51-OZ). According to the law, agricultural enterprises, which lands are currently located near the Ring Road of St.Petersburg and transferred to other category of land will be available from the land reserve of the Leningrad region. In Table 1 the dynamic of changes in land use in the Leningrad region from 2006 to 2013 is presented.

Table 1. The dynamic of changes in land use in the Leningrad region from 2006 to 2013 (th.hectares).

\begin{tabular}{|l|l|l|l|l|l|l|}
\hline Land category & $\mathbf{2 0 0 6}$ & $\mathbf{2 0 0 7}$ & $\mathbf{2 0 0 8}$ & $\mathbf{2 0 0 9}$ & $\mathbf{2 0 1 1}$ & $\mathbf{2 0 1 3}$ \\
\hline Agricultural lands & 1711,3 & 1710,8 & 1708,7 & 1701,1 & 1706,2 & 1704,7 \\
\hline Settlement lands & 231,3 & 231,5 & 232 & 233,7 & 234,6 & 235,6 \\
\hline $\begin{array}{l}\text { Lands of industry, } \\
\text { transport, } \\
\text { communications and } \\
\text { so on }\end{array}$ & 379,6 & 379,2 & 382,2 & 383,5 & 383,7 & 384,7 \\
\hline $\begin{array}{l}\text { Specially protected } \\
\text { lands }\end{array}$ & 41,4 & 41,3 & 41,3 & 41,3 & 41,7 & 41,8 \\
\hline Forest lands & 4757,1 & 4757,8 & 4757,9 & 4756,6 & 4756,6 & 4756,6 \\
\hline Lands of water fund & 1081,6 & 1081,6 & 1081,6 & 1081,6 & 1081,3 & 1081,3 \\
\hline Reserve lands & 188,5 & 188,6 & 187,1 & 187 & 186,7 & 186,1 \\
\hline
\end{tabular}

As it can be seen from Table 1, there is a stable trend of increasing area of settlement lands and lands of industry by reducing agricultural land area in the Leningrad region as a whole.

Totally, in five municipalities of the Leningrad region, adjacent to the city of St. Petersburg (the first belt agglomeration), the area of agricultural land has decreased in 2011-2012 to 2268.93 hectares. The agricultural lands have a maximum rate in land categories changes within the suburbs of St. Petersburg. These changes do not affect the overall structure of the land fund area. The area and the number of agricultural land parcels affected by land categories changes in the suburbs of St. Petersburg (ha) is presented in Table 2.

Table 2 shows that the leader of transfer of agricultural lands to the settlement lands and the industry lands is Vsevolozhsky municipality. 790.62 hectares of agricultural lands were transferred to the settlement lands in this municipality Only during the 2011-2012. Also 510.52 hectares of agricultural land were transferred to industrial land. Mainly transfer of lands to another category associated with the enlargement of the settlements for the new 
housing development, including cottage settlements. Transfer to industrial lands was caused mainly by the new industrial development [33].

Industrial zones territories include land parcels of industrial enterprises, warehouses and logistics facilities. There are a significant area of industrial zones in the territories of suburban settlements (3.1 thousand hectares). Within the city of St. Petersburg (the core of the metropolis) industrial zones are concentrated mainly in the industrial-residential zone (2,7 thousand hectares), on the outer industrial areas (1.9 thousand hectares) and adjacent to the core of the city industrial-residential zones of the city centre (770 hectares) [36, 37].

Table 2. The area (hectares) and the number of agricultural land parcels effected by land categories changes in the suburbs of St. Petersburg.

\begin{tabular}{|l|l|l|l|l|}
\hline Municipalities & $\begin{array}{l}\text { To the settlement } \\
\text { lands (area), } \\
\text { hectares }\end{array}$ & $\begin{array}{l}\text { To the settlement } \\
\text { lands (number of } \\
\text { parcels) }\end{array}$ & $\begin{array}{l}\text { To the lands of } \\
\text { industry, transport, } \\
\text { communications } \\
\text { and so on (area), } \\
\text { hectares }\end{array}$ & $\begin{array}{l}\text { To the lands of } \\
\text { industry, transport, } \\
\text { communications } \\
\text { and so on (number } \\
\text { of parcels) }\end{array}$ \\
\hline Vsevolozhsky & 790,62 & 100 & 510,52 & 78 \\
\hline Kirovsky & - & - & 0,48 & 1 \\
\hline Tosnensky & 67,94 & 8 & 238,51 & 18 \\
\hline Gatchinsky & 305,57 & 13 & 99,17 & 11 \\
\hline Lomonosovsky & 150,15 & 9 & 102,78 & 15 \\
\hline
\end{tabular}

The process of new development of the St. Petersburg suburbs is growing every year. MUDP of St. Petersburg currently included the territories of settlements-satellites in the Leningrad region. About 200 objects of town-planning activity, including zones of complexes of residential buildings, social objects, industrial and warehouse, terminal and business complex is planned to be created on these territories. In the future, with the development of agglomeration, the process of increasing land settlements and industry mainly due to agricultural land will be continued. This fact is evidenced by the trend of recent years.

\section{Conclusions}

Analysis of spatial aspect on urban planning in St. Petersburg areas showed that changes in the structure of the city planning caused corresponding changes in the spatial economic zoning of the city's territory. This situation developed in the results of the state cadastral land evaluation in St. Petersburg and made it necessary to adjust the terms and conditions of land use payments.

\section{References}

1. I. Mohd, F. Ahmad, W.A. Wan Abd Aziz, Journal of Facilities Management, 7(4), 307318 (2009).

2. I. Tosics, Journal of Housing and the Built Environment, 19, 67-90 (2004).

3. N.V. Vatin, O.S. Gamayunova, D.V. Nemova, Applied Mechanics and Materials, 638640, 2460-2464 (2014).

4. K. Beardsley, J.H. Thorne, N.E. Roth, S. Gao, M.C. McCoy, Landscape Urban Plan, 93, 172-183 (2009).

5. V. Badenko, N. Arefiev, Applied Mechanics and Materials, 617, 302-306 (2014). 
6. A. Duffy, Int. J. Life Cycle Ass, 14, 268-277 (2009).

7. A. Makarov, A.Mihailova, N. Arefiev, S. Pavlov, T. Chashchina, V. Terleev, V. Badenko, Procedia Engineering, 117, 225-231 (2015).

8. Arefiev N., Badenko V., Nikonorov A., Terleev V., Volkova Yu., Procedia Engineering, 117, 20-25 (2015).

9. B. Gleeson, Urban Stud, 49, 931-943 (2012).

10. M.Y. Zubkova, et al, Advanced Materials Research, 587-589, 330-337 (2014).

11. R.A. Poluektov, V.V. Terleev, Russian Meteorology and Hydrology, 12, 73-77 (2005).

12. S. Ognjenovic, R. Donceva, N. Vatin, Procedia Engineering, 17(1), 556-563 (2015).

13. A. Nikonorov, S. Pavlov, V. Terleev, N. Arefiev, V. Badenko, Y. Volkova, Procedia Engineering, 117, 258-263 (2015).

14. P.J. O’Farrell, P.M.L. Anderson, Curr. Opin. Environ. Sust, 2, 59-65 (2010).

15. M.Y. Zubkova, V.I. Maslikov, D.V. Molodtsov, A.N. Chusov, Advanced Materials Research, 941-944, 2107-2111 (2014).

16. S. Medvedev, A. Topaj, V. Badenko, V. Terleev, IFIP Advances in Information and Communication Technology, 448, 252-261 (2015).

17. V. Badenko, V. Terleev, A. Topaj, Applied Mechanics and Materials, 635-637, 16881691 (2014).

18. N. Arefiev, V. Terleev, V. Badenko, Procedia Engineering, 117, 39-44 (2015).

19. S. Sala, F. Farioli, A. Zamagni, Int. J. Life Cycle Ass, 18, 1653-1672 (2013).

20. M. Scholz, A. Hedmark, W. Hartley, J. Environ. Plann. Manage, 55, 833-854 (2012).

21. D. Kurtener, V. Badenko, Journal of the Brazilian Computer Society, 6, 26-32 (2000).

22. D. Kurtener, V. Badenko, Geomatics Info Magazine, 15, 76-79 (2001).

23. L. Vasilevska, P. Vranic, A. Marinkovic, Cities, 36, 83-92 (2014).

24. N. Arefiev. M. Mikhalev, et al, Procedia Engineering, 117, 32-38 (2015).

25. R. Camagni, M.C. Gibelli, P. Rigamonti, Ecol. Econ, 40, 199-216 (2002).

26. Yu.V. Ryazanov, V.F. Kovyazin, V.L. Bogdanov, Vestnik Sankt-Peterburgskogo Universiteta, Seriya Geologiya i Geografiya, 2, 58-65 (2009).

27. C. Turcu, Progress in Planning, 78, 101-150 (2012).

28. V. Terleev, V. Badenko, I. Guseva, W. Mirschel, Applied Mechanics and Materials, 725-726, 355-360 (2015).

29. N. Arefiev, V. Garmanov, V. Bogdanov, Yu. Ryabov, V. Terleev, V. Badenko, Procedia Engineering, 117, 26-31 (2015).

30. V.V. Terleev, W. Mirschel, U. Schindler, K.-O. Wenkel, Journal International Agrophysics, 24(4), 381-387 (2010).

31. L.E. Limonov, T.V. Vlasova, ICSR "Leontief Centre", St. Petersburg, 2012.

32. St. Petersburg Law "On General Plan of St. Petersburg and the boundaries of zones of protection of cultural heritage on the territory of St. Petersburg", 2005 № 728-99.

33. S.A. Korotkov, V.L. Bogdanov, Proceedings of the St. Petersburg Agrarian University, 33, 195-199 (2013).

34. V.V. Garmanov, V. Kutsenko, G.K. Osipov, D.V. Tripolnikova, S.I. Nosov, Land management, a cadastre and monitoring of lands, 118(10), 51 - 60 (2014). 